\title{
Krzysztof Cieślikowski
}

Akademia Wychowania Fizycznego w Katowicach

e-mail: k.cieslikowski@awf.katowice.pl

\section{SEGMENTACJA UCZESTNIKÓW SPOTKAŃ KONFERENCYJNYCH JAKO PODMIOTÓW RYNKU TURYSTYKI BIZNESOWEJ}

\section{SEGMENTATION OF CONFERENCE \\ MEETINGS PARTICIPANTS AS PLAYERS \\ OF THE BUSINESS TOURISM MARKET}

DOI: $10.15611 /$ pn.2018.535.02

JEL Classification: M31, Z32, Z33, L88, P25, R58

\begin{abstract}
Streszczenie: Celem artykułu jest wskazanie kluczowych kryteriów efektywnej segmentacji uczestników konferencji. Przypuszcza się, że z punktu widzenia zarówno administracji miasta, jak i organizatorów wydarzeń kluczowe kryteria efektywnej segmentacji to, te które pozwolą na przygotowywanie interesującej oferty, elastyczne zarządzanie cenami, a także prowadzenie skutecznych kampanii promocyjnych i sprzedażowych w celu przyciągnięcia i obsługi określonych gości konferencyjnych. Do osiągnięcia celu oraz weryfikacji postawionej hipotezy zastosowano metody obserwacji czynnej i analizy opracowań literaturowych zagranicznych i krajowych, a także wyniki opracowań własnych. Autor dokonuje identyfikacji i opisu kryteriów segmentacji uczestników spotkań konferencyjnych z wykorzystaniem procedury a priori i post hoc. Do kluczowych kryteriów zaliczył: miejsce zamieszkania uczestnika, rodzaj instytucji, którą reprezentuje uczestnik, długość pobytu uczestnika, wykorzystany przez uczestnika środek transportu..
\end{abstract}

Słowa kluczowe: marketing destynacji, rynek turystyczny, turystyka biznesowa, segmentacja rynku.

Summary: The aim of the article is to indicate the key criteria for effective segmentation of participants of conferences. The author assumes that from the point of view of the city administration and event organizers, the key criteria for effective segmentation are those that allow preparing an interesting (attractive) offer, flexibly manage prices, and implement effective promotional and sales campaigns for attracting and serving conference guests. To achieve the main aim of the work, the methods of active observation and analysis of foreign and national literature studies as well as the results of own research were used. The author identifies and describes the criteria for the segmentation of participants of conference meetings using the a priori and post hoc procedures. The key participants included: the place of residence of the participant, the type of institution represented by the participant, the length of the participant's stay and the means of transport used by the participant.

Keywords: destination marketing, tourism market, business tourism, market segmentation. 


\section{Wstęp}

Rynek turystyczny na świecie, pomimo zawirowań politycznych i gospodarczych, a także zagrożeń terrorystycznych czy też kataklizmów naturalnych, rozwija się dynamicznie [UNWTO 2017]. W Polsce po stronie podaży tego rynku zauważyć można z roku na rok coraz więcej hoteli [Emmerson Evaluation 2017], wielofunkcyjnych obiektów spotkań [MSiT 2016], powoływane są specjalne komórki organizacyjne w strukturach administracji terytorialnej do skutecznego zarządzania rozwojem turystyki w destynacji; natomiast po stronie popytu rośnie liczba odwiedzających Polskę, zwiększa się aktywność turystyczna mieszkańców Polski [WTTC 2017], ale także odnotowywana jest coraz większa liczba wydarzeń, w tym biznesowych [Dziedzic, Celuch 2012; Raport 2016; Hotel Media Group 2017], i liczby uczestników [GUS 2017]. Rozwój rynku turystycznego wywołuje także konieczność marketingowego podejścia do zarządzania turystyką w obszarze recepcji turystycznej [Cieślikowski, Żemła 2002]. Dla wielu miast ważnym klientem na rynku turystycznym jest osoba przyjeżdżająca służbowo na spotkania konferencyjne [Berbeka i in. 2014; Cieślikowski 2015]. Zastosowanie segmentacji rynku turystyki biznesowej w celu podejmowania efektywnych działań w zakresie kształtowania oferty, cen, promocji i sprzedaży usług uczestnikom konferencji wydaje się niezbędne.

Różne formy spotkań konferencyjnych i innych wydarzeń biznesowych określane są terminem turystyka biznesowa [Davidson, Cope 2003; Cieślikowski 2015]. W spotkaniach tych uczestniczą zarówno odwiedzający daną miejscowość, jak i mieszkańcy. Uczestnicy pełnią różne role w tych spotkaniach (prelegent, delegat, gość specjalny itp.), jak i w organizacjach, które reprezentują (np. ze względu na zajmowane stanowisko). Są to klienci indywidualni zainteresowani niektórymi usługami związanymi z realizacją spotkań konferencyjnych. Różnią się oni wieloma cechami geodemograficznymi, ekonomicznymi i innymi. Przydatne jest zatem wskazanie kluczowych kryteriów efektywnej segmentacji uczestników spotkań konferencyjnych jako podmiotów na rynku turystyki biznesowej.

Z punktu widzenia zarówno administracji miasta, jak i organizatorów wydarzeń, kluczowe wydają się kryteria efektywnej segmentacji, które pozwolą przygotowywać interesującą (atrakcyjną) ofertę wydarzenia i pobytu gości, elastycznie zarządzać cenami różnych usług, a także realizować skuteczne kampanie promocyjne i sprzedażowe w celu przyciągania i obsługi gości konferencyjnych. Autor poprzez metody obserwacji biernej oraz czynnej i analizy danych głównie ze źródeł wtórnych (raportów dot. turystyki biznesowej na świecie i w Polsce), a także wyników badań własnych (zrealizowanych już badań turystyki biznesowej, głównie w województwie śląskim) stara się w artykule przedstawić różne kryteria stosowane przy segmentacji uczestników spotkań konferencyjnych i określić te kluczowe dla efektywnej segmentacji. Wykorzystuje do tego także procedury a priori i post hoc. Opisane i analizowane kryteria segmentacji uczestników konferencji mogą posłużyć zarządzającym turystyką biznesową w destynacjach, jak i w obiektach konferencyjnych w Polsce do poprawy 
atrakcyjności ich oferty i rozwoju turystyki biznesowej. Tematyka segmentacji na rynku turystyki biznesowej nie została jeszcze dokładnie opisana. Artykuł ma charakter przeglądowy, a zarazem prezentuje szerokie spektrum możliwych kryteriów segmentacji uczestników konferencji ze wskazaniem tych kluczowych dla efektywnego przygotowywania i rozwoju oferty na rynku turystyki biznesowej.

\section{Uczestnik konferencji jako podmiot rynku turystyki biznesowej}

Rynek w ujęciu ekonomicznym to zarówno ogół kupujących i sprzedających, jak i relacje między nimi. Sprzedawcy, mający do zaoferowania przedmioty wymiany, stanowią stronę podażową rynku, a nabywcy, zgłaszający zapotrzebowanie i zainteresowanie zakupem, stronę popytową rynku. Podstawowymi kryteriami podziału są: kryterium przedmiotów wymiany, kryterium podmiotów rynku, kryterium przestrzenne [Wrzosek 2002]. W ujęciu marketingowym rynek to klienci mający określone potrzeby lub pragnienia, którzy w celu ich zaspokojenia są gotowi i są w stanie dokonać wymiany [Kotler 2005].

Niestrój [2002] w marketingowej interpretacji rynku zwraca uwagę na to, iż:

- u podstaw przedmiotowego wyodrębniania rynków nie leżą produkty, lecz ich główne funkcje użytkowe, wyrażające się w zdolności do zaspokajania określonych potrzeb,

- rynek w wymiarze podmiotowym to rodzaj konsumentów i nabywców tworzących popyt na różnego rodzaju produkty,

- czynnikiem rozstrzygającym o geograficznym rynku przedsiębiorstwa jest zasięg skutecznego oddziaływania oferty, przy założeniu należytej dbałości o jej rozpropagowanie. Inaczej mówiąc, rynek przestrzenny kończy się tam, gdzie nie ma już rzeczywistych i potencjalnych klientów.

Osoby przemieszczające się poza miejsce stałego zamieszkania są nabywcami tworzącymi popyt na określone usługi, stanowią one w ujęciu marketingowym rynek turystyczny [Panasiuk 2007; Gołembski (red.) 2009]. Każdy rynek (także turystyczny) może być dalej dezagregowany według różnych kryteriów [Altkorn 2005].

Uwzględniając główny cel podróży (znajdujący wyraz w potrzebach głównych), a także sposób jej finansowania, rynek turystyczny można podzielić na: rynek turystyki czasu wolnego (główny cel to wypoczynek, finansowany głównie z funduszy własnych uczestnika wyjazdu) oraz rynek podróży służbowych, w tym turystyki biznesowej (główny cel związany z wykonywanym zawodem, wyjazd finansowany w całości lub w znacznej części przez instytucję delegującą uczestnika wyjazdu). Zauważyć należy, że termin „turystyka biznesowa” odnosi się raczej do spotkań grupowych [Davidson, Cope 2003].

Przyjmując za kryterium podziału rynku klientów na rynku turystyki biznesowej charakter odbiorcy i sposób jego postępowania, zauważyć można: klienta indywidualnego i klienta instytucjonalnego. Te dwie grupy klientów różnią się m.in.: skalą zakupów, powtarzalnością zamówień, racjonalizacją motywów zakupów, charakterem 
podejmowanych decyzji zakupowych (indywidualnie czy zespołowo), partnerskim charakterem więzi usługodawcy z usługobiorcą (nabywcą) i innymi (tab. 1).

Tabela 1. Nabywca instytucjonalny a nabywca indywidualny

\begin{tabular}{|c|c|c|}
\hline Kryteria & Nabywca instytucjonalny & Nabywca indywidualny \\
\hline Cel zakupów & $\begin{array}{l}\text { dalszy rozwój organizacji, } \\
\text { instytucji }\end{array}$ & zakupy na własne potrzeby \\
\hline Charakter popytu & pochodny & pierwotny \\
\hline Motywy zakupu & $\begin{array}{l}\text { racjonalne, względnie tatwo } \\
\text { przewidywalne }\end{array}$ & $\begin{array}{l}\text { często emocjonalne, wynikające } \\
\text { z osobistych potrzeb i preferencji }\end{array}$ \\
\hline $\begin{array}{l}\text { Częstotliwość i wartość } \\
\text { transakcji }\end{array}$ & duża wartość i powtarzalność & $\begin{array}{l}\text { mała wartość i nieregularność, } \\
\text { a nawet jednorazowość }\end{array}$ \\
\hline Determinanty popytu & $\begin{array}{l}\text { głównie czynniki techniczno- } \\
\text {-ekonomiczne }\end{array}$ & $\begin{array}{l}\text { czynniki ekonomiczne } \\
\text { i pozaekonomiczne }\end{array}$ \\
\hline Procedury zakupu & według określonych procedur & $\begin{array}{l}\text { pod wpływem emocji, mody, medium } \\
\text { i kampanii promocyjnych }\end{array}$ \\
\hline $\begin{array}{l}\text { Znaczenie usług przed- } \\
\text { i posprzedażowych }\end{array}$ & bardzo duże & niewielkie \\
\hline $\begin{array}{l}\text { Znaczenie sprawności } \\
\text { w procesie świadczenia } \\
\text { usług }\end{array}$ & bardzo duże & niewielkie \\
\hline $\begin{array}{l}\text { Procedura kształtowania } \\
\text { cen }\end{array}$ & wynik negocjacji & $\begin{array}{l}\text { akceptacja cen oferowanych przez } \\
\text { usługodawcę, rzadko negocjacje }\end{array}$ \\
\hline $\begin{array}{l}\text { Elastyczność cenowa } \\
\text { popytu }\end{array}$ & niewielka & $\begin{array}{l}\text { zróżnicowana w zależności od } \\
\text { potrzeb i motywów zakupów }\end{array}$ \\
\hline Kanały dystrybucji & krótkie/płytkie & długie/głębokie \\
\hline $\begin{array}{l}\text { Znaczenie relacji osobistych } \\
\text { dostawca-odbiorca }\end{array}$ & bardzo duże, relacje imienne & niewielkie, często anonimowe \\
\hline Komunikacja rynkowa & charakter dwukierunkowy & $\begin{array}{l}\text { dominuje jeszcze charakter } \\
\text { jednokierunkowy }\end{array}$ \\
\hline
\end{tabular}

Źródło: opracowanie na podstawie [Karcz, Kędzior 1999; Gołębiowski (red.) 2003; Kotler, Pfoertsch 2008].

Klienci instytucjonalni na rynku turystyki biznesowej to dwie główne grupy nabywców: przedsiębiorstwa (jako organizacje nastawione na zysk) oraz organizacje rządowe i pozarządowe [Davidson, Cope 2003]. Cechuje tych nabywców racjonalność motywów zakupu, duża wartość jednorazowych zakupów i powtarzalność transakcji. Dużą wagę przywiązują do osobistych, imiennych kontaktów z dostawcą. Nabywcy ci także różnią się: przedmiotem działalności, preferowaną tematyką spotkań, wielkością spotkań, częstotliwością ich realizacji, sposobem finansowania, preferowanymi dniami tygodnia i miesiącami $\mathrm{w}$ roku, preferowanymi obiektami konferencyjnymi, kryteriami wyboru miejsca [Cieślikowski 2014]. 
Na rynku turystyki biznesowej można wymienić także uczestników spotkań konferencyjnych. Są to aktywne podmioty tego rynku, gdyż zauważalna jest pewna samodzielność w podejmowaniu decyzji przez klienta indywidualnego - uczestnika konferencji. Dotyczy to decyzji o wyjeździe i udziale w konferencji czy też wyborze miejsca docelowego (destynacji, a nawet obiektu noclegowego). Klienci indywidualni (konsumenci) na tym rynku w pewnym stopniu samodzielnie organizują podróż i samodzielnie kupują usługi z nią związane, a także podejmują decyzje o wydatkach w miejscu docelowym. Zatem warto ich obserwować, rozpoznać ich potrzeby i doskonalić proces ich obsługi. Klienci indywidualni różnią się wieloma kryteriami, które można spotkać także na innych rynkach, jednak na rynku turystyki biznesowej klient indywidualny - uczestnik spotkań konferencyjnych, reprezentuje organizację która go oddelegowała do udziału. Zatem motywy uczestnictwa prywatne (nieoficjalne) będą przeplatały się z oficjalnymi (instytucjonalnymi). Rozpoznanie tych potrzeb może być ważne dla segmentacji indywidualnych uczestników w różnych spotkaniach biznesowych.

\section{Segmentacja jako kluczowy etap zarządzania marketingowego}

Segmentacja jest pierwszym etapem zarządzania marketingowego skoncentrowanego na zaspokajaniu potrzeb określonych grup docelowych klientów. Polega na podziale rynku na oddzielne grupy nabywców, którzy mogą wymagać osobnych (różnych) produktów i/lub odrębnego marketingu-mix [Kotler 2005]. Na jej dużą rolę w efektywnym zarządzaniu przedsiębiorstwem zwrócił uwagę już w latach 50. ubiegłego wieku Smith [1956].

Dla wielu przedsiębiorstw typ klienta (indywidualny czy też instytucjonalny) stanowi główne kryterium segmentacji i podstawę do dalszej dezagregacji rynków [Szulce i in. 2004]. Skuteczna segmentacja pozwala na wybór rynków docelowych (targeting) i ustalenia cech, które pozwolą zarówno przedsiębiorstwu, jak i destynacji prowadzić pozycjonowanie oferty [Cieślikowski, Żemła 2002].

Proces segmentacji obejmuje kilka etapów [Sarabia 1996; Kotler 2005; Kusińska 2009; McDonald, Wilson 2012]: identyfikację zmiennych (kryteriów) segmentacji i podział rynku na segmenty, a następnie opracowanie profili zidentyfikowanych segmentów rynku, które będą rozważane jako możliwe do podjęcia aktywności w zakresie działań marketingu-mix.

Rynek turystyki biznesowej w ujęciu marketingowym można określić jako zbiór aktualnych i potencjalnych zleceniodawców spotkań i wydarzeń biznesowych oraz klientów indywidualnych - uczestników tych wydarzeń. Efektywna segmentacja tego rynku powinna zakładać wyodrębnienie użytecznych dla przedsiębiorstwa lub destynacji segmentów rynku, spełniających wymagania efektywnej segmentacji. W literaturze [Kotler 2005] wymienia się następujące warunki:

- wymierność (można zmierzyć liczbę podmiotów, ich siłę nabywczą),

- znaczny rozmiar (segmenty są wystarczające duże i zyskowne), 
- dostępność (do segmentów można dotrzeć z informacją, obsłużyć go),

- możliwość odróżnienia (segmenty w odmienny sposób reagują na marketing-mix),

- możliwość działania (można sformułować programy przyciągania i obsługiwania klientów).

Turystyka biznesowa może być rozpatrywana jako produkt przedsiębiorstw (hoteli, organizatorów konferencji), ale także jako produkt destynacji [Anholt 2007; Nowacki, Zmyślony 2012; Cieślikowski 2015]. Organizacja i obsługa tego produktu pozwala na wykorzystanie posiadanej już infrastruktury ogólnej w mieście (z której korzystają mieszkańcy i odwiedzający), ale też wymaga infrastruktury specjalnie do tego przygotowanej (centra kongresowe, wystawowe, poprawa dostępności komunikacyjnej itp.). Turystyka biznesowa staje się dla administracji miast pretekstem do rozbudowy istniejących czy też budowy nowych obiektów spotkań. Powstają wielofunkcyjne nowoczesne areny (stadiony), w których realizowane są także spotkania konferencyjne i inne wydarzenia biznesowe. Miasta wykorzystują turystykę biznesową do swojej promocji - komunikacji zorientowanej na określone grupy docelowe odbiorców [Cieślikowski 2017]. W proces koordynacji działań w zakresie komunikacji z klientami indywidualnymi włączają się także convention bureau [Latuszek 2017]. Zatem znajomość klientów docelowych na tym rynku i ich efektywna segmentacja wydają się kluczowe w podejmowaniu decyzji o dalszym kierunku rozwoju miasta z wykorzystaniem turystyki biznesowej.

\section{Wybrane kryteria efektywnej segmentacji uczestników spotkań konferencyjnych}

W procedurze segmentacji rynku i doboru kryteriów stosuje się podejście a priori (nazywane tradycyjnym) i post hoc (nazywane rozbudowanym, nowoczesnym) [Mirek 2000; Nowacki, Zmyślony 2012].

$\mathrm{W}$ przypadku segmentacji a priori przyjmuje się wcześniej pewne zmienne niezależne, które są podstawą grupowania klientów, i określa ich związek (lub wpływ) na zmienne zależne, którymi najczęściej są: preferencje określonych marek, zamiary zakupu, wielkości wydatków na dane dobra/usługi itp. Do podstawowych kryteriów segmentacji w wielu opracowaniach zalicza się społeczno-demograficzne cechy konsumentów. Po uzyskaniu informacji o tych cechach dokonuje się grupowanie konsumentów i tworzy na tej podstawie profile segmentów.

Segmentacja post hoc jest odwróceniem procedury a priori, tzn. kryteriami tej procedury segmentacji są zmienne związane z poszukiwaniem korzyści preferencji produktu, wzorami zakupu itp., które nie są wyodrębnione arbitralnie, lecz jako efekt procesu wielowymiarowego grupowania i skalowania [Manczak 2013]. Segmentacja post hoc w dużej mierze bazuje na zestawieniu zmiennych pozwalających zbadać preferencje nabywców [Craft i in. 2003]. Ostateczne kryteria segmentacji wytypowane zostaną po przeprowadzeniu badań empirycznych. W podejściu post 
hoc mają zastosowanie kryteria oparte na zmiennych psychograficznych lub związane z oczekiwanymi korzyściami wynikającymi z użytkowania produktu. W segmentacji post hoc $\mathrm{w}$ trakcie opracowywania danych stosuje się analizę czynnikową, a następnie zastosowanie ma analiza skupień [Kotler 2005]. W tym podejściu do segmentacji można zastosować także skalowanie wielowymiarowe, które pozwala na zróżnicowanie segmentów pomiędzy sobą [Bąk, Wawrzyniak 2008].

Dokonując przeglądu wybranych badań rynku turystyki biznesowej w Polsce [Berbeka i in. 2014; Dziedzic, Celuch 2012; Cieślikowski 2017], można zauważyć pewne kryteria podziału klientów indywidualnych na rynku turystyki biznesowej, które są kluczowe dla efektywnej segmentacji uczestników spotkań konferencyjnych, z punktu widzenia zarówno administracji miast, jak i organizatorów spotkań konferencyjnych i innych wydarzeń biznesowych. Do tych kryteriów zaliczyć można:

- zmienne geodemograficzne (wiek uczestników, płeć, miejsce zamieszkania),

- zmienne emporiograficzne (rodzaj instytucji, którą reprezentują: przedsiębiorstwa/korporacje, organizacje non profit, administrację publiczną, a także wielkość instytucji pod względem liczby pracowników),

- aktywność konferencyjna delegatów (uwzględniającą liczbę spotkań biznesowych, w których uczestniczyli w określanym czasie),

- podział delegatów ze względu na rodzaj spotkania biznesowego (uczestnicy konferencji i kongresów; uczestnicy targów i wystaw; uczestnicy wydarzeń motywacyjnych; uczestnicy wydarzeń korporacyjnych),

- dostępność spotkania konferencyjnego (spotkania otwarte, zamknięte, mieszane),

- rodzaj obiektu, w którym identyfikuje się uczestników (hotel, inne obiekty, w tym: centrum wystawiennicze/kongresowe, obiekt/sala na specjalne wydarzenie, obiekt edukacyjny/akademicki),

- długość pobytu uczestnika (jeden dzień - bez noclegu, dwa dni lub dłużej),

- preferowane środki transportu uczestników spotkań konferencyjnych (w tym: osobowy samochód, transport kolejowy, komunikacja miejska, przewozy taxi, autobus dalekobieżny czy też samolot),

- identyfikacja głównych motywacji uczestnictwa w spotkaniach konferencyjnych (z ich podziałem na motywy oficjalne i nieoficjalne),

- percepcja miasta docelowego jako miejsca spotkań konferencyjnych i wydarzeń biznesowych (z uwzględnieniem dostępności komunikacyjnej, bazy noclegowej, bazy konferencyjnej, gastronomicznej, a także możliwości rekreacji w czasie wolnym czy też zrobienia zakupów),

- struktura i wielkość wydatków uczestników spotkań konferencyjnych (wyrażona w złotówkach lub innej walucie wielkość wydatków; podział wydatków na różne rodzaje usług; podział wydatków ze względu na czas ich realizacji: przed wyjazdem, w trakcie pobytu i po konferencji; podział wydatków ze względu na miejsce wydatków: obiekty konferencyjny, poza obiektem konferencyjnym; a także podział na wydatki poniesione prywatnie $\mathrm{i}$ te pokrywane przez instytucję delegująca). 
W badaniach satysfakcji uczestników spotkań konferencyjnych i oceny konferencji spotyka się ciekawe, z punktu widzenia promocji konferencji, kryterium „główne/pierwsze źródło informacji o konferencji” (przełożony kolega w miejscu pracy, portale społecznościowe, inne). W zagranicznych badaniach [Rogers 2013] zauważyć można dodatkowo podział uczestników ze względu na:

- funkcje uczestnika w wydarzeniu (delegaci - reprezentujący instytucje, prelegenci - przemawiający w trakcie konferencji, VIP - goście specjalni/sponsorzy, pracownicy organizatora i wystawców),

- poziom zaangażowania uczestnika w proces kontaktu $\mathrm{z}$ organizatorem i formę udziału w wydarzeniu (uczestnicy aktywni ,full registrants": wypełnią formularze, będą na wydarzeniu; osoby towarzyszące „visitors registrants” - będą na wydarzeniu, ale zainteresowani raczej programem czasu wolnego i zwiedzaniem destynacji; uczestnicy bierni, tzw. „auxiliary participants” - chcą mieć informacje o wydarzeniu, ale i tak się na nim nie pojawią, mogą natomiast być dobrymi promotorami wydarzenia).

Uczestników spotkań konferencyjnych można podzielić na grupy według różnych kryteriów. Zrozumienie specyfiki wyodrębnionych grup klientów indywidulnych może mieć istotne znaczenie dla świadomego wyboru rynku docelowego przez administracje miast czy też organizatorów spotkań konferencyjnych.

\section{Zakończenie}

Rynek turystyki biznesowej w Polsce rozwija się zarówno po stronie podażowej, jak i popytowej. Analiza raportów dotyczących tego rynku pozwala zauważyć, że kluczowymi kryteriami segmentacji uczestników spotkań konferencyjnych mogą być:

- miejsce zamieszkania uczestnika,

- rodzaj instytucji, którą reprezentują uczestnicy,

- długość pobytu uczestnika,

- sposób dotarcia na spotkanie konferencyjne.

Zauważa się, iż większe wydatki w miejscowości docelowej generują uczestnicy przyjeżdżający z dalszych miejsc, którzy zazwyczaj spędzają dłuższy czas w miejscowości konferencyjnej niż uczestnicy z pobliskich miejscowości, którzy są jeden dzień (kilka godzin). Ponadto uczestnicy reprezentujący przedsiębiorstwa/korporacje chętniej przybywają samochodami, preferują hotele jako miejsca konferencji (z uwagi na kompleksowe usługi i łatwość dotarcia samochodem) i przyjeżdżają raczej na krótsze pobyty [Cieślikowski 2017]. Uczestnicy przebywający jeden dzień ponoszą kilkukrotnie mniejsze wydatki w miejscowości docelowej niż uczestnicy dłuższych pobytów. Ponadto jednodniowy uczestnik rzadziej korzysta z usług dodatkowych w obiekcie konferencyjnym czy w miejscowości docelowej.

Badania wskazują, że samochodem osobowym przyjeżdża większość uczestników spotkania konferencyjnego, a samolot stanowi główny środek transportu dla gości zagranicznych. W związku z tym, planując konferencję, należy uwzględnić te 
grupy klientów i zapewnić dostępność komunikacyjną (oznakować dojazdy, opisać trasę z lotniska itp.). Dostępność komunikacyjna stanowi ważny punkt odniesienia dla oceny miejscowości konferencyjnej, a także samego obiektu.

Zarządzający turystyką biznesową w mieście, jak i organizatorzy spotkań konferencyjnych, dokonując rozpoznania klientów indywidualnych oraz ich potrzeb przy zastosowaniu kluczowych kryteriów segmentacji, mogą aktywnie przygotowywać interesującą (atrakcyjną) ofertę, kształtować ceny, a także realizować skuteczne kampanie promocyjne i sprzedażowe w celu przyciągania i obsługi gości konferencyjnych.

\section{Literatura}

Altkorn J., 2005, Marketing w turystyce, Wydawnictwo Naukowe PWN, Warszawa.

Anholt S., 2007, Competitive Identity: The New Brand Management for Nations, Cities and Regions, Palgrave Macmillan, Basingstoke.

Bąk I. ,Wawrzyniak K., 2008, Segmentacja europejskiego rynku turystycznego, Wiadomości Statystyczne, nr 4.

Berbeka J., Borodako K., Niemczyk A., Seweryn R., 2014, Wpływ ekonomiczny przemystu spotkań na gospodarkę Krakowa, Fundacja Uniwersytetu Ekonomicznego w Krakowie, Kraków.

Cieślikowski K., 2014, Rynek turystyki konferencyjnej, t. I: Podstawy teoretyczne. Funkcjonowanie i rozwój na świecie, Akademia Wychowania Fizycznego, Katowice.

Cieślikowski K., 2015, Zarzadzanie turystyka biznesową. Wybrane aspekty globalne i lokalne, AWF, Katowice.

Cieślikowski K., 2017, Rynek turystyki biznesowej w Katowicach. Badanie rynkowe uczestników spotkań, Convevtion Bureau, Katowice.

Cieślikowski K., Żemła M., 2002, Pozycjonowanie obszaru recepcji turystycznej z wykorzystaniem map percepcji, Marketing i Rynek, nr 2.

Craft S., Hassan S., Kortam W., 2003, Understanding the new bases for global segmentation, Journal of Consumer Marketing, vol. 20(5).

Davidson R., Cope B., 2003, Turystyka biznesowa. Konferencje, podróże, motywacje, wystawy, turystyka korporacyjna, POT, Warszawa.

Dziedzic E., Celuch K., 2012, Raport. Przemyst spotkań i wydarzeń w Polsce, POT, Warszawa.

Emmerson Evaluation, 2017, Rynek hotelowy w Polsce, Warszawa.

Gołębiowski T. (red.), 2003, Marketing na rynku instytucjonalnym, PWE, Warszawa.

Gołembski G. (red.), 2009, Kompendium wiedzy o turystyce, Wydawnictwo Naukowe PWN, Warszawa.

GUS, 2017, Mass Events in 2016. Report based on data from a statistical survey, Kraków.

Hotel Media Group, 2017, Rynek obiektów konferencyjnych w Polsce, Warszawa.

Karcz K., Kędzior Z, 1999, Marketing przemysłowy. Wybrane zagadnienia, Akademia Ekonomiczna, Katowice.

Kotler P., 2005, Marketing, Dom Wydawniczy Rebis, Poznań.

Kotler P., Pfoertsch W., 2008, Zarządzanie marka w segmencie B2B, Wydawnictwo Naukowe PWN, Warszawa.

Kusińska A., 2009, Segmentacja rynku i typologia konsumentów, Instytut Badań Rynku, Konsumpcji i Koniunktur, Warszawa.

Latuszek N., 2017, Role convention bureau w świetle badań empirycznych, Prace Naukowe Uniwersytetu Ekonomicznego we Wrocławiu, nr 473, s. 422-432. 
Manczak I., 2013, Identyfikacja segmentów rynku turystycznego miasta-założenia koncepcyjne, Handel Wewnętrzny, nr 6 (347).

McDonald M., Wilson H., 2012, Plany marketingowe, Wolters Kluwer Polska, Warszawa.

Mirek J., 2000, Kryteria segmentacji rynku, Zeszyty Naukowe, nr 543, Akademia Ekonomiczna w Krakowie.

MSiT, 2016, Duże hale sportowo-widowiskowe w Polsce. Inwentaryzacja bazy sportowej, Warszawa

Niestrój R., 2002, Zarządzanie marketingiem. Aspekty strategiczne, Wydawnictwo Naukowe PWN, Warszawa-Kraków.

Nowacki M., Zmyślony P., 2012, Segmentacja rynku turystycznego na podstawie pomiaru percepcji wizerunku miasta, Ekonomiczne Problemy Usług, nr 84, Zeszyty Naukowe Uniwersytetu Szczecińskiego, nr 699, s. 227-240.

Panasiuk, 2007, Rynek turystyczny i mechanizmy jego funkcjonowania, [w:] Kurek W. (red.), Turystyka, Wydawnictwo Naukowe PWN, Warszawa.

Raport, 2016, Wplyw ekonomiczny przemystu spotkań na gospodarkę Polski, Poland Meetings Impact 2015, SGTiR, Warszawa.

Rogers T., 2013, Conferences and Conventions: A Global Industry (third edition), Butterworth-Heinemann, Oxford.

Sarabia F., 1996, Model for market segments evaluation and selections, European Journal of Marketing, no. 4.

Smith W., 1956, Product differentiation and market segmenation as alternative marketing strategis, Joumal of Marketing, no. 21, s. 3-8.

Szulce H., Florek M., Walkowiak K., 2004, Segmentacja jako podstawa zróżnicowania działań marketingowych, Acta Universitatis Lodziendzis Folia Oeconomica, t. 179, s. 273-284.

UNWTO, 2017, Tourism Highlights 2017 Edition, Madrid.

Wrzosek W., 2002, Funkcjonowanie rynku, PWE, Warszawa.

WTTC, 2017, Travel \& Tourism Economic Impact 2017, Poland, World Travel \& Tourism Council, London.

Zmyślony P., 2013, Internacjonalizacja zarządzania funkcją turystyczna w dużym mieście, Prace Geograficzne, z. 134, s. 51-67. 